\title{
Correction: Mitotane-induced dyspnoea: an unusual side effect
}

Farooq AU, Amjad W, Kochar T, et al. Mitotane-induced dyspnoea: an unusual side effect. BMJ Case Rep 2018. doi:10.1136/bcr-2018-225490.

This article contains an error in the list of affiliations. The correct list reads as follows:

Ali U Farooq, ${ }^{1}$ Waseem Amjad, ${ }^{2}$ Tanureet Kochar, ${ }^{3}$ Shubash Adhikari ${ }^{3}$

${ }^{1}$ Department of Cardiovascular Medicine, Charleston Area Medical Center, Charleston, West Virginia, USA

${ }^{2}$ Department of Digestive Diseases, Mercy Medical Center, Baltimore, Maryland, USA

${ }^{3}$ Department of Internal Medicine, Charleston Area Medical Center, Charleston, West Virginia, USA

The article is also missing an acknowledgement statement, which reads as follows:

The authors would like to thank Frank H Annie, Charleston Area Medical Center Health Education and Research Institute, for research support as well as Abhishek Bhagat, Charleston Area Medical Center Department of Internal Medicine and Fatima Ahmed, Charleston Area Medical Center Department of Internal Medicine for general support for this project.

C BMJ Publishing Group Limited 2019. No commercial re-use. See rights and permissions. Published by BMJ.

BMJ Case Rep 2019;12:e225490corr1. doi:10.1136/bcr-2018-225490corr1

Check for updates

Copyright 2018 BMJ Publishing Group. All rights reserved. For permission to reuse any of this content visit https://www.bmj.com/company/products-services/rights-and-licensing/permissions/

BMJ Case Report Fellows may re-use this article for personal use and teaching without any further permission.

Become a Fellow of BMJ Case Reports today and you can:

- Submit as many cases as you like

- Enjoy fast sympathetic peer review and rapid publication of accepted articles

- Access all the published articles

Re-use any of the published material for personal use and teaching without further permission

For information on Institutional Fellowships contact consortiasales@bmjgroup.com

Visit casereports.bmj.com for more articles like this and to become a Fellow 